\title{
Morphogenetic and structural characteristics of tillers of guinea grass of different age and grazing severities
}

\section{Denise Baptaglin Montagner ${ }^{1}$, Domicio do Nascimento Júnior ${ }^{2}$, Braulio Maia de Lana Sousa ${ }^{2}$ Hélio Henrique Vilela ${ }^{2}$, Valéria Pacheco Batista Euclides ${ }^{1}$, Sila Carneiro da Silva ${ }^{3}$, André Fischer Sbrissia ${ }^{4}$, Marciele Neves Carloto ${ }^{1}$}

\footnotetext{
1 EMBRAPA Gado de Corte, Campo Grande, MS

2 Departamento de Zootecnia - UFV, Viçosa, MG.

${ }^{3}$ Departamento de Zootecnia - USP/ESALQ, Piracicaba, SP.

${ }^{4}$ Departamento de Produção Animal e Alimentos - UDESC, Lages, SC.
}

\begin{abstract}
The objective of this research was to evaluate the effects of tiller age on morphogenic and structural characteristics of guinea grass cv. Mombaca subjected to intermittent stocking and three stubble heights: $30 \mathrm{~cm}, 50 \mathrm{~cm}$ and 50-30 cm. Stubble heights were assigned to experimental units in a completely randomized block design with three replicates. Grazing was performed when canopy intercepted 95\% of light incidence. Leaf appearance rate, leaf elongation rate and number of live leaves per tiller were higher in the summer when compared with the winter. Contrarily, stem elongation rate, phyllochron and leaf lifespan were lower in the summer when compared with the winter. During the summer, young tillers had higher leaf appearance and elongation rates when compared with the older ones. Young and mature tillers had the highest values of live leaves per tiller in the summer. There was no difference between summer and winter for the final length of leaf blade between tillers of the same age, except in mature tillers, which had higher final leaf length during the summer. Senescence rate of leaves was higher in young tillers, followed by mature and old tillers. Age of tiller affects morphogenic and structural characteristics of pasture, showing that young tillers have better growth compared with mature and old tillers.
\end{abstract}

Key Words: ecophysiology, light interception, Panicum maximum, stubble height

\section{Introduction}

Pastures are comprised of plant population, and each plant is formed by basic units called tillers, as in the case of forage grasses (Valentine and Matthew, 1999). Therefore, the understanding of the processes that determine growth and development of pastures involves knowing the processes occurring in individual tillers. Forage accumulation in pastures results from the total of all the units which compose it (Matthew et al., 2001). The study of morphogenic and structural characteristics has contributed to the understanding of the process of biomass accumulation under a grazing system. This knowledge enables the management of pasture conditions such as frequency and severity of defoliation (Da Silva et al., 2009; Pena et al., 2009). Thus, recent research (Carnevalli et al., 2006; Barbosa et al., 2007; Giacomini et al., 2009a,b; Mesquita et al., 2010) indicates that the optimal time for regrowth coincides with interruption at interception of $95 \%$ of incident light by the canopy.

However, the severity of defoliation still needs to be adjusted (Sousa et al., 2010; Sousa et al., 2011). When pasture conditions are maintained relatively constant throughout the year, severe grazing promotes a high potential of tissue renewal with high accumulation of leaf blades and effective control of stem accumulation, while lenient grazing results in increased stem accumulation, but in intense use of the pastures during favorable times for plant growth (Difante et al., 2009 a,b). However, varying the grazing severity along the year can be an interesting alternative, resulting in better yield of pastures in the growth season and the control of stem accumulation during the fall and the winter.

However, because pastures are formed by tillers at different stages of development, they have, at the same time, tillers at variable vegetative development cycles and also tillers at the reproductive stage (Paiva, 2009). So, tillers can respond individually to the management practices employed, depending on their stage of development.

This research aimed to study the morphogenic and structural characteristics of tillers of Panicum maximum cv. Mombaca of different ages subjected to different severities of grazing under intermittent stocking. 


\section{Material and Methods}

The experiment was developed at Embrapa Gado de Corte(CNPGC), in Campo Grande, MS (20²7' S, 54³7' W; 530 m of altitude) between September 2005 and April 2007. According to Köppen's classification, the climate of the region is wet tropical savannah (subtype Aw), characterized by uneven distribution of annual rainfall with well-defined occurrence of dry (May - Sept) and rainy (Oct - Apr) periods.

The climatic conditions data during the experimental period (Figures 1 and 2) were collected at Embrapa Gado de Corte weather station, located about 4,000 $\mathrm{m}$ away from the experimental site. Values of average temperature and accumulated monthly rainfall were used to calculate the water balance.

The grazing system was established in February of 1994. After soil analysis, corrections and fertilization which consisted of applying 3,700 kg/ha of dolomitic limestone (PRNT = 73\%), $500 \mathrm{~kg} / \mathrm{ha}(0-20-15$ formulation $)$ and $50 \mathrm{~kg} / \mathrm{ha}$ of FTE BR-12 - were carried out. Afterwards, viable pure seeds of guinea grass cv. Mombaca (Panicum maximum cv. Mombaca) were sown (2 kg/ha). Seeds were incorporated into soil by slight harrowing and then compacted with a tire-wheeled compacting tractor.

The soil is classified as Dystrophic Red Latosol (EMBRAPA, 1999), clayey texture, acid $\mathrm{pH}$, low base saturation and high concentration of aluminum, and, based on the chemical analyses performed at the beginning of the trial $(0-20 \mathrm{~cm})$, presented the following characteristics: $\mathrm{pH}$ in $\mathrm{H}_{2} \mathrm{O}=5.05 ; \mathrm{P}=2.03$ (Mehlich-1) and $\mathrm{K}=150.90 \mathrm{mg} / \mathrm{dm}^{3}$; $\mathrm{Ca}^{+2}=1.95 ; \mathrm{Mg}^{+2}=1.25 ; \mathrm{Al}^{+3}=0.03 ; \mathrm{H}+\mathrm{Al}=3.81$ and CTC $(\mathrm{t})=3.59 \mathrm{cmol}_{\mathrm{c}} / \mathrm{dm}^{3} ; \mathrm{V}=48.5 \%$.

Pastures have been grazed since their establishment in 1994. In October 2004, 1,000 kg/ha of dolomitic limestone (85\% PRNT) and $800 \mathrm{~kg} / \mathrm{ha}$ of agricultural phosphogypsum were applied. In November 2005, 400 kg/ha of NPK (0-20-20 formulation) and $200 \mathrm{~kg} / \mathrm{ha}$ of nitrogen (urea) were applied. In October 2006, 400 kg/ha of NPK (0-20-20 formulation)

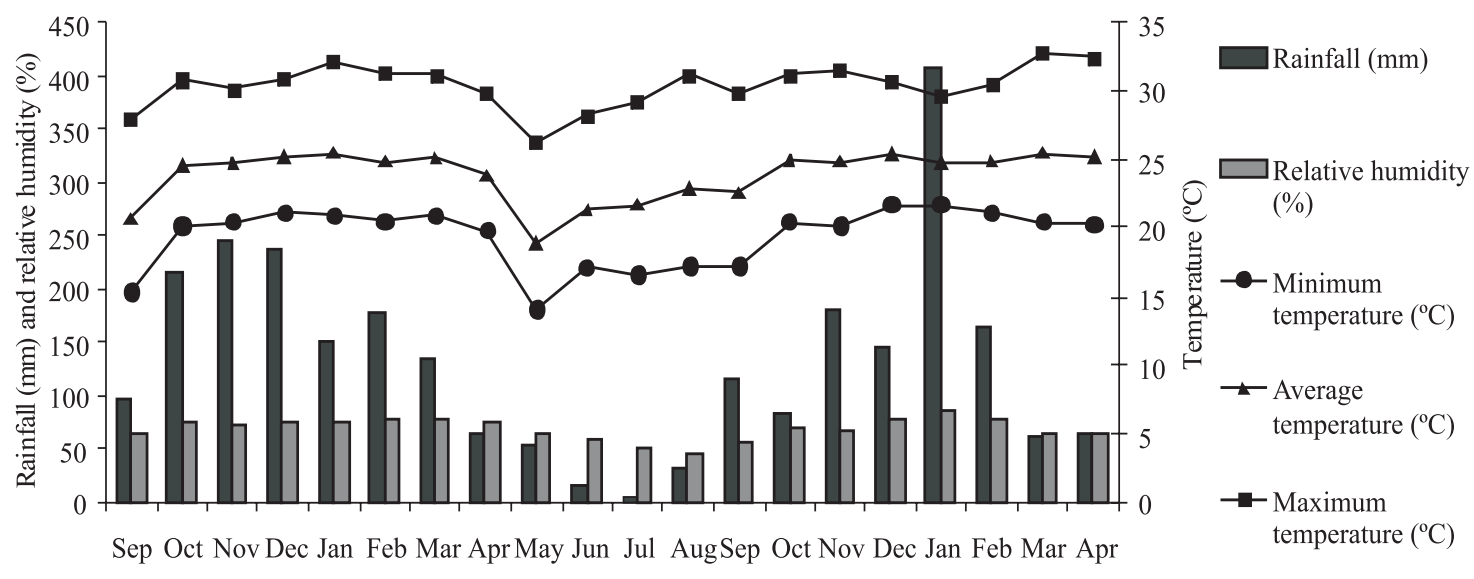

Figure 1 - Accumulated monthly rainfall, average relative air humidity, and minimum, medium and maximum temperatures between September 2005 and April 2007.

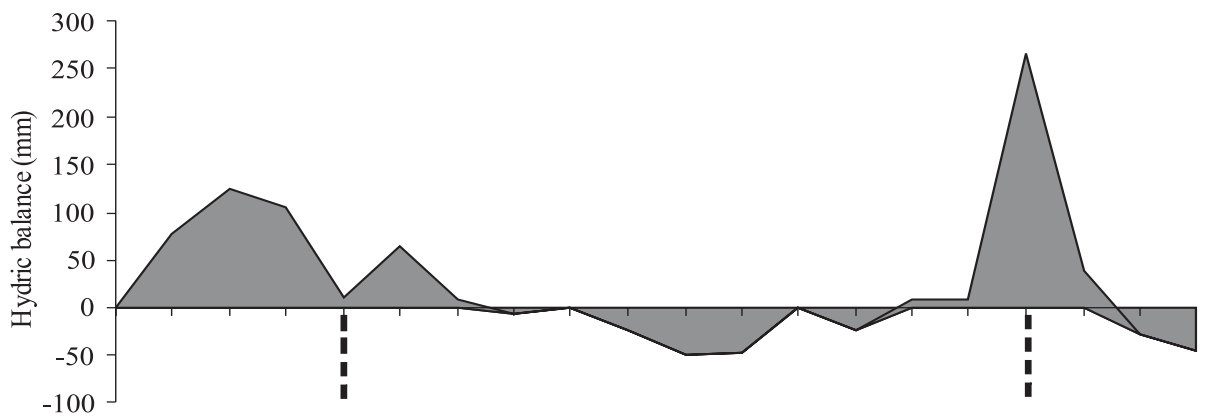

Sep Oct Nov Dec Jan Feb Mar Apr May Jun Jul Aug Sep Oct Nov Dec Jan Feb Mar Apr 2005

2006

2007

Figure 2 - Monthly water balance during the trial from September 2005 to April 2007. 
and $100 \mathrm{~kg} / \mathrm{ha}$ of nitrogen were applied. In this period, it was not possible to apply all the pre-established dose of urea (200 kg/ha), since the experiment was finished after the second grazing cycle on Feb 02, 2007. After grazing in each paddock, nitrogen was applied in a split manner, during the rainy period.

Three grazing severities, characterized by stubble postgraze heights were evaluated: severe post-graze height $(30 \mathrm{~cm})$, representing intense forage use; lenient $(50 \mathrm{~cm})$, showing higher individual animal performance; and $50-30 \mathrm{~cm}$ ( $50 \mathrm{~cm}$ stubble from spring and summer, lowered to $40 \mathrm{~cm}$ in the first fall grazing, then to $30 \mathrm{~cm}$ in the following grazing, and returning to $50 \mathrm{~cm}$ after the first spring grazing). The aim was to obtain higher pasture growth and greater individual animal performance in the spring and summer, and reduced stem accumulation and senescent material in the fall and winter. All grazings were performed when plants reached $95 \%$ of light interception during regrowth. The post-grazing heights were allocated to the experimental units ( $0.25 \mathrm{ha}$ ) in a completely randomized block design with three replicates.

The grazing system used was rotational, utilizing, on average, 18-month crossbred steers, with average weight of $310 \mathrm{~kg}$. The grazing interval was determined by light interception of the forage canopy during regrowth. Light interception was monitored in the post-grazing period during pasture regrowth until pre-graze, through a canopy analyzer AccuPAR Linear PAR/LAI ceptometer, Model PAR 80 (DECAGON Devices) at 30 reading spots per yard, following $\mathrm{W}$-shaped trajectories. In each spot, a reading was taken above the canopy and another on the soil surface (below the canopy).

Sward height was measured in association with the evaluations of LI by a ruler, with which 40 readings were performed in each experimental unit. The average of the experimental unit corresponded to the average of the 40 spots.

The ratoons used in the monitoring of the demographic standards of tillering allowed to obtain tillers of different ages through the marking of new tillers that appeared in each grazing cycle (tillering dynamics). Two morphogenic evaluations of the tiller ages were conducted. The first evaluation was performed in the dry season, from June to August 2006, totaling 70 days. In this evaluation, the first marking was done in the spring of 2005, due to the impossibility to determine the real age of the tillers. Therefore, tillers of the second generation onwards were utilized. The second evaluation was conducted in the summer of 2007, from February to April, comprising a grazing interval, which was variable in each experimental unit.

Tiller age was classified as follows: old tillers (over 4 months of age), mature tillers (2 to 4 months of age) and young tillers (less than 2 months of age). In the four ratoons used for the tillering demographic standards, nine tillers were chosen, that is, three of each age, amounting to 12 young, old and mature tillers in each experimental unit. As the first generation of tillers was discarded and because only three grazing cycles were performed for the stubble height of $30 \mathrm{~cm}$, it was not possible to obtain old tillers for this condition in the first evaluation.

The features evaluated were: leaf appearance rate (leaves/tiller.day), leaf elongation rate (cm/tiller.day), leaf senescence rate (cm/tiller.day), phyllochron (days/leaf), stem elongation rate ( $\mathrm{cm} /$ tiller.day), leaf lifespan (days/leaf), final length of leaf blade $(\mathrm{cm})$ and number of live leaves (leaves/tiller).

Data were investigated in a split plot scheme of time, in which the post-graze heights constituted the plots, and the seasons of the year, the subplots. The variance analyses of the weighted means per season presented no heterogeneity of variances and, therefore, the ANOVA was performed. The GLM procedure of the SAS statistical package (SAS Institute, 1996) was used, in which the RANDOM and TEST commands were adopted. The comparison of means was done by Tukey's test at $5 \%$ level of significance.

\section{Results and Discussion}

The pre-grazing sward height was not influenced by post-grazing heights, seasons of the year or interaction between post-grazing and seasons of year $(\mathrm{P}>0.05)$. Therefore, the condition of $95 \%$ of light interception was reached at $93 \mathrm{~cm}$ of sward height, regardless of the season of the year. This is similar to the results obtained by Carnevalli etal.(2006) for the guinea grass cv. Mombaca $(90 \mathrm{~cm})$. As corroborated by previous studies, the relation between light interception and pre-grazing sward height is consistent and extremely stable for different plant species and cultivars (Carnevalli et al., 2006; Barbosa et al., 2007; Pedreira et al., 2007; Trindade et al.; Sousa et al., 2010; Sousa et al., 2011).

The post-grazing heights evaluated did not affect $(\mathrm{P}>0.05)$ the morphogenic or structural characteristics of tillers of different ages. Barbosa (2004), evaluating guinea grass cv. Tanzania under grazing and rotational stock, did not find effect of post-grazing heights on the morphogenic or structural characteristics of tillers of different ages, either. Sousa et al. (2010), in studying Andropogon grass with different severity cuts, also observed the same standard of morphogenic and structural characteristics of the canopy. The condition of $95 \%$ of light interception is considered adequate for the regrowth interruption (Da Silva \& Nascimento Júnior, 2007). Afterwards, competition for light 
incidence is intensified. So, the plants of tropical climate show stem elongation as an adapted response to allocate their leaves to the canopy surface, and accelerate the senescence process and death of leaves, once the number of live leaves kept in a tiller is relatively constant. Since the defoliation frequency was the same (95\% of light interception), the absence of the significant effect of morphogenic and structural characteristics on post-grazing heights is indicative that the severity tested was adequate for the guinea grass cv. Mombaca and did not affect the remaining leaf area and/or the organic reserves. Thus, the choice of the defoliation severity is attributed to the productive system, to the desired pasture efficiency (Difante et al., 2009a,b), to the soil fertility level and to the adequate corrections and fertilizers (Da Silva et al., 2008).

Stem elongation rate, phyllochron and leaf lifespan were influenced only by the seasons of the year $(\mathrm{P}<0.05)$. Then, during the summer, smaller stem elongation rate, phyllochron and leaf lifespan were observed (Table 1).

There was no interaction between heights, ages and seasons nor differences between post-grazing heights $(\mathrm{P}>0.05)$, for leaf appearance rate and leaf elongation rate, number of live leaves and final length of leaf blade, in terms of tiller ages and the two seasons under evaluation.
However, there was interaction between tiller ages in the seasons under evaluation $(\mathrm{P}<0.05)$ (Table 2$)$.

Regardless of tiller ages, the winter presented the lowest leaf appearance rate and leaf elongation rate (Table 2) and the highest stem elongation rate, phyllochron and leaf lifespan (Table 1) in comparison with the summer. The morphogenic and structural characteristics are regulated mainly by natural resources' conditions such as luminosity, water availability, temperature and nitrogen supply (Lemaire \& Chapman, 1996; Lemaire \& Agnusdei, 2000). Then, whenever the availability of growth resources decreases (winter), the plant reduces its flow of tissues as a mechanism to stay alive, diminishing, therefore, the use of its organic reserves.

There was no difference between summer and winter regarding the final length of leaf blade between tillers of the same age, except for mature tillers, which presented longer final length of leaf blade during the summer (Table 2). During the growth period of the plants, the final length of leaf blade tends to increase according to the increment of the average length of sheaths (pseudostem), due to the longer distance the leaf needs to go through until its appearance (Lemaire \& Chapman, 1996; Duru \& Ducrocq, 2000). Certainly, stem size kept relatively constant between

Table 1 - Morphogenic and structural characteristics of guinea grass cv. Mombaca in two seasons of the year

\begin{tabular}{lccc}
\hline Variable & \multicolumn{2}{c}{ Season } & Summer \\
\cline { 2 - 3 } & Winter & $-0.034 \mathrm{~B}$ & SEM \\
\hline Stem elongation rate (cm/tiller.day) & $0.004 \mathrm{~A}$ & $16 \mathrm{~B}$ & 0.020 \\
Phyllochron (days/leaf) & $98 \mathrm{~A}$ & 6.2 & $\mathrm{~B}$ \\
Leaf lifespan (days/leaf) & $195 \mathrm{~A}$ & 11.8 \\
\hline
\end{tabular}

SEM = standard error of the mean

Different capital letters on the same row are different by Tukey’s test $(\mathrm{P}<0.05)$.

Table 2 - Morphogenic and structural characteristics of tillers of different ages of guinea grass cv. Mombaca in two seasons of the year

\begin{tabular}{|c|c|c|c|}
\hline \multirow[t]{2}{*}{ Season } & \multicolumn{3}{|c|}{ Tiller age } \\
\hline & Old & Mature & Young \\
\hline & \multicolumn{3}{|c|}{ Leaf appearance rate (leaves/tiller.day) } \\
\hline Winter & $0.01 \mathrm{aB}$ & $0.01 \mathrm{aB}$ & $0.01 \mathrm{aB}$ \\
\hline \multirow[t]{2}{*}{ Summer } & $0.06 \mathrm{bA}$ & $0.08 \mathrm{abA}$ & $0.09 \mathrm{aA}$ \\
\hline & \multicolumn{3}{|c|}{ Leaf elongation rate ( $\mathrm{cm} /$ tiller.day) } \\
\hline Winter & $0.45 \mathrm{aB}$ & $0.33 \mathrm{aB}$ & $0.36 \mathrm{aB}$ \\
\hline \multirow[t]{2}{*}{ Summer } & $1.67 \mathrm{cA}$ & $3.44 \mathrm{bA}$ & $4.54 \mathrm{Aa}$ \\
\hline & \multicolumn{3}{|c|}{ Number of live leaves (leaves/tiller) } \\
\hline Winter & $2.0 \mathrm{aB}$ & $1.9 \mathrm{aB}$ & $2.1 \mathrm{aB}$ \\
\hline \multirow[t]{2}{*}{ Summer } & $3.5 \mathrm{bA}$ & $4.4 \mathrm{aA}$ & $4.7 \mathrm{aA}$ \\
\hline & \multicolumn{3}{|c|}{ Final length of leaf blade $(\mathrm{cm})$} \\
\hline Winter & $16.3 \mathrm{bA}$ & 19.7bB & $30.8 \mathrm{aA}$ \\
\hline Summer & $16.5 \mathrm{bA}$ & $29.3 \mathrm{aA}$ & $34.6 \mathrm{aA}$ \\
\hline
\end{tabular}

Standard error of the mean for leaf appearance rate (0.003), leaf elongation rate (0.2), number of live leaves (0.1) and final length of leaf blade (1.6).

Different lowercase letters on the same row are different $(\mathrm{P}<0.05)$ by Tukey's test.

Different capital letters on the same column are different $(\mathrm{P}<0.05)$ by Tukey's test. 
winter and summer for the young and old tillers, which may have determined this standard.

The rates of processes responsible for the biomass accumulation in a pasture, namely leaf appearance rate and leaf elongation rate, as well as number of live leaves per tiller, were not altered by tiller age during the winter (Table 2). Nevertheless, during the summer, young tillers had better capacity of forage production, as observed in the variations of leaf appearance rate and leaf elongation rate (Table 2) than the old and mature tillers. This standard determined similar variations of the structural characteristic of the canopy, mainly in terms of number of live leaves and final length of leaf blade (Table 2), similarly to results obtained by Carvalho (2002) in studies with guinea grass cv. Mombaca and Tanzania, Barbosa (2004) with guinea grass cv. Tanzania and Paiva (2009) with Marandu palisadegrass. Young tillers also presented longer leaves during the winter and summer, showing that old tillers had leaves with shorter final length, regardless of the season of the year (Table 2). Despite having longer stems, old tillers may have shown elevated apical meristem, reducing the distance that the new leaf had to go through until its appearance, decreasing the final length of leaf blade (Lemaire \& Chapman, 1996; Duru \& Ducrocq, 2000). Possibly, the higher growth observed in young tillers may be attributed to their photosynthetic capacity. According to Carvalho (2002), there is reduction of photosynthetic capacity of tillers as they age, probably, related to the anatomical and physiological changes of the leaves. However, studies on this subject are scarce.

Leaf senescence rate was influenced only by tiller age $(\mathrm{P}<0.05)$. Young tillers presented higher leaf senescence rate $(1.1 \mathrm{~cm} /$ tiller.day), followed by mature tillers, $(0.9 \mathrm{~cm} /$ tiller.day) and finally, by old tillers ( $0.1 \mathrm{~cm} /$ tiller.day), possibly due to the accelerated growth rate of young tillers. These results corroborate those obtained by Barbosa (2004) for the guinea grass cv. Tanzania and Paiva (2009) for the Marandu palisadegrass, showing that tiller age influences the morphogenic and structural characteristics of plants, resulting in progressive loss of vigor as tillers age. Therefore, grazing management systems (e.g., frequency and severity of defoliation, nitrogen supply) that favor a rapid regrowth of tillers would be desirable, since young tillers present higher growth rates (Barbosa, 2004).

\section{Conclusions}

The age range of the tillers alters the morphogenic and structural characteristics of pastures, given that young tillers present increased growth vigor as compared with both mature and old tillers.

\section{References}

BARBOSA, R.A. Características morfofisiológicas e acúmulo de forragem em capim-tanzânia (Panicum maximum Jacq. cv. Tanzânia) submetido a frequências e intensidades de pastejo. 2004. 100f. Tese (Doutorado em Zootecnia) Universidade Federal de Viçosa, Viçosa, MG.

BARBOSA, R.A.; NASCIMENTO JÚNIOR, D.; EUCLIDES, V.B.P. et al. Capim-tanzânia submetido a combinações entre intensidade e frequência de pastejo. Pesquisa Agropecuária Brasileira, v.42, n.3, p.329-340, 2007.

CARNEVALLI, R.A.; DA SILVA, S.C.; BUENO, A.A.O. et al. Herbage production and grazing losses in Panicum maximum cv. Mombaca under four grazing managements. Tropical Grasslands, v.40, p.165-176, 2006.

CARVALHO, D.D. Leaf morphogenesis and tillering behavior in single plants and simulated swards of guinea grass (Panicum maximum Jacq.) cultivars. 2002. 186f. Thesis (Doctor of Philosophy in Plant Science) - Massey University, Massey, USA.

DA SILVA, S.C.; NASCIMENTO JÚNIOR, D. Avanços na pesquisa com plantas forrageiras tropicais em pastagens: características morfofisiológicas e manejo do pastejo. Revista Brasileira de Zootecnia, v.36, n.4, p.121-138, 2007 (supl. especial).

DA SILVA, S.C.; NASCIMENTO JÚNIOR, D.; EUCLIDES, V.B.P. Pastagens: Conceitos básicos, produção e manejo. Viçosa, MG: Suprema, 2008. 115p.

DA SILVA, S.C.; BUENO, A.A.O.; CARNEVALLI, R.A. et al. Sward structural characteristics and herbage accumulation of Panicum maximum cv. Mombaça subjected to rotational stocking managements. Scientia Agricola, v.66, n.1, p.8-19, 2009.

DIFANTE, G.S.; NASCIMENTO JÚNIOR, D.; EUCLIDES, V.P.B. et al. Sward structure and nutritive value of tanzania guineagrass subjected to rotational stocking managements. Revista Brasileira de Zootecnia, v.38, n.1, p.9-19, 2009a.

DIFANTE, G.S.; EUCLIDES, V.P.B.; NASCIMENTO JÚNIOR, D. et al. Ingestive behavior, herbage intake and grazing efficiency of beef cattle steers on Tanzania guineagrass subjected to rotational stocking managements. Revista Brasileira de Zootecnia, v.38, n.6, p.1001-1008, 2009b.

DURU, M; DUCROCQ, H. Growth and senescence of the successive grass leaves o a tiller ontogenic development and effect of temperature. Annals of Botany, v.85, p.635-643, 2000.

EMPRESA BRASILEIRA DE PESQUISA AGROPECUÁRIA EMBRAPA. Serviço Nacional de Levantamento e Conservação de Solos. Sistema brasileiro de classificação de solos. 2.ed. Rio de Janeiro: Embrapa Solos, 2006. 306p.

GIACOMINI, A.A.; DA SILVA, S.C.; SARMENTO, D.O.L. et al. Components of the leaf area index of marandu palisadegrass swards subjected to strategies of intermittent stocking. Scientia Agricola, v.66, n.6, p.721-732, 2009a.

GIACOMINI, A.A.; DA SILVA, S.C.; SARMENTO, D.O.L. et al. Growth of marandu palisadegrass subjected to strategies of intermittent stocking. Scientia Agricola, v.66, n.6, p.733-741, 2009b.

LEMAIRE, G.; AGNUSDEI, M. Leaf tissue turn-over and efficiency of herbage utilization. In: LEMAIRE, G.; HODGSON, J.; MORAES, A.; NABINGER, C.; CARVALHO; P.C.F. (Eds.) Grassland ecophysiology and grazing ecology. Wallingford: CAB International, 2000. p.265-288.

LEMAIRE, G.; CHAPMAN, D. Tissue flows in grazed plant communities. In: HODGSON, J.; ILLIUS, A.W. (Eds.). The ecology and management of grazing systems. Wallingford: CAB International, 1996. p.3-36.

MATTHEW, C.; VAN LOO, E.N.; THOM, E.R. et al. Understanding shoot and root development. INTERNATIONAL GRASSLAND CONGRESS, 19., 2001, Piracicaba, Proceedings... Piracicaba: FEALQ, 2001. p.19-27. 
MESQUITA, P.; DA SILVA, S.C.; PAIVA, A.J. et al. Structural characteristics of marandu palisadegrass swards subjected to continuous stocking and contrasting rhythms of growth. Scientia Agricola, v.67, n.1, p.23-30, 2010.

PAIVA, A.J. Características morfogênicas e estruturais de faixas etárias de perfilhos em pastos de capim-marandu submetidos à lotação contínua e ritmos morfogênicos contrastantes. 2009. 104f. Dissertação (Mestrado em Ciência Animal e Pastagens) - Escola Superior de Agricultura "Luiz de Queiroz"/Universidade de São Paulo, Piracicaba.

PEDREIRA, B.C.; PEDREIRA, C.G.S.; DA SILVA, S.C. Estrutura do dossel e acúmulo de forragem de Brachiaria brizantha cv. Xaraés em resposta a estratégias de pastejo. Pesquisa Agropecuária Brasileira, v.42, n.2, p.281-287, 2007.

PENA, K.S.; NASCIMENTO JÚNIOR, D.; DA SILVA, S.C. et al. Características morfogênicas, estruturais e acúmulo de forragem do capim-tanzânia submetido a duas alturas e três intervalos de corte. Revista Brasileira de Zootecnia, v.38, n.11, p.2127-2136, 2009 .
SOUSA, B.M.L; NASCIMENTO JÚNIOR, D.; DA SILVA, S.C. et. al. Morphogenetic and structural characteristics of Andropogon grass submitted to different cutting heights. Revista Brasileira de Zootecnia, v.39, n.10, p.2141-2147, 2010.

SOUSA, B.M.L; NASCIMENTO JÚNIOR, D.; RODRIGUES, C.S et al. Morphogenetic and structural characteristics of Xaraes palisadegrass submitted to cutting heights. Revista Brasileira de Zootecnia, v.40, n.1, p.53-59, 2011.

STATISTICAL ANALYSES SYSTEM - SAS. SAS/STAT. User's guide statistics - versão 6, 4.ed. Cary: 1996. v.1,2.

TRINDADE, J.K.; DA SILVA, S.C.; SOUZA JÚNIOR, S.J. et al. Composição morfológica da forragem consumida por bovinos de corte durante o rebaixamento do capim-marandu submetido a estratégias de pastejo rotativo. Pesquisa Agropecuária Brasileira, v.42, n.6, p.883-890, 2007.

VALENTINE, I.; MATTHEW, C. Plant growth, development and yield. In: WHITE, J.; HODGSON, J. (Eds.). New Zealand pasture and crop science. Oxford: Cambridge University Press, 1999. p.11-28. 